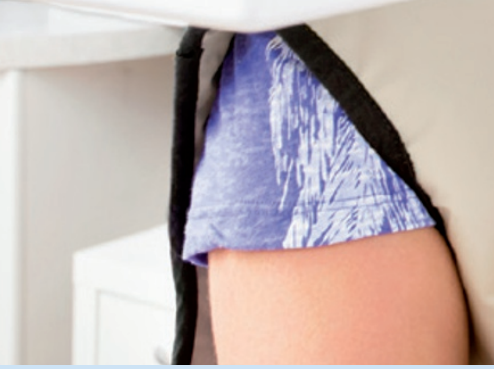

\section{TRAINING IN THE MIDLANDS}

We are a provider of dental nurse training in the Midlands and were wondering whether we could be included in your publication please?

We offer the following courses:

\section{Training for Health}

- NEBDN National Diploma in

Dental Nursing

- NEBDN Certificate in

Dental Radiography

- NEBDN Certificate in Dental Sedation Nursing
- NEBDN Certificate in Special Care Dental Nursing

- Dental Sedation Update

- Royal Society of Public Health Level 2 Award in Health Promotion (Oral Health).

For more information see the following website: www.trainingforhealth.derbys. nhs.uk, telephone 01773599472 or email trainingforhealth@dchs.nhs.uk.

\section{Claire Petchey}

Training for Health Administrator

\title{
HIGHER EDUCATION IN PROFESSIONAL PRACTICE
}

The University of Kent Centre for Professional Practice offers the following course which may be of interest to Vital readers:

\section{Advanced and Specialist Healthcare}

(Applied Dental Professional Practice) PG Cert, PG Dip and MSc

Modules include:

- Evidence Based Practice

- Professional Standard Setting

- Dentistry in a Contemporary Context

- Research Skills
- Inter-Professional Working

- Advancing Dental Practice

- Mentorship

- Dissertation.

For more information visit www.kent.ac.uk/cpp, telephone 01634 888929 or email cppmedway@kent.ac.uk.

Kirsty Logan

Programme and Marketing Coordinator

University of Kent

Derbyshire Community Health Services

\section{NORFOLK SMILES}

We are a company called Smiles Dental Training and offer a variety of courses in Norfolk for DCPs:

- NEBDN National Diploma in Dental Nursing

- NEBDN National Certificate in Oral Health Education

- Topical Fluoride Application

- CPD courses

- Work-based oral health education.

For more information visit www.smilesdentaltraining.co.uk, email smilesdentaltraining@hotmail.com or telephone 07789937993.

\section{Anna Lown \\ Course Director \\ Smiles Dental Training}

